\title{
The Impact of Inflowing Labors on Macau Wages: Evidence in Macau
}

\author{
Ya-Nan Song \\ Faculty of Administration and Management, Macau University of Science and Technology, Macau, China \\ ynsong@must.edu.mo
}

\begin{abstract}
With the rapid economic growth, importing outside labors become main method to alleviate employed population insufficiency in Macau. This paper establishes vector autoregressive (VAR) model and uses the impulse response analysis investigating the interaction effects and response path between inflowing labors and wages in various industries based on 2003-2011 quarterly data. The results of the study showed that inflowing labors would play long-term effects on manufacturing, construction, financial and tourism industrial wages. Besides inflowing labor in construction industry will faintly pull up the wages in its own industry, the same effects also happened in the other three industries, which indicated the cheap inflowing labors lower the wage costs and enhanced human resources supply in Macau. And although the import of outside labor reduces the average wages of tourism industry, positive effects on wages of other industries have been showed in a long-term crescendo which indicating the tourism as the leading industry to absorb the employed population and other industries need more inflowing labors to satisfy their job vacancy. The findings emphasize that the industrial wages really affected by inflowing labors are those with specific technical ability requirements and local workers are incapable of.

Index Terms - Inflowing Labors, Wages, VAR Model, Impulse Response
\end{abstract}

\section{Introduction}

The growing presence of foreign workers has sparked a continuing debate in labor importing countries in East Asia on the social and economic consequences of labor inflows and the policy options for dealing with the 'foreign worker problem'. A key concern of this debate is that influx of cheap foreign labor suppresses domestic wage growth, with adverse implication for long-term growth and improvement of economic welfare of native citizens. The same story occurs in Macau who has been experiencing a rapid economic development and one of the fastest growing economies in Asia with above 20\% GDP growth rate per years. The quick development of tourism and gambling industry which accounts over $40 \%$ of total economy causes native workers heavily gathering in this fast growing and well paid industry, and the rest of the occupations are lack of labors due to this unbalanced development. In 1988, Macau government started importing outside labors by passing the $12 / \mathrm{GM} / 88$ and 49/GM/88 DC to solve the shortage in native labor market. By 2012, there are above one million foreign labors entering Macau, however inflowing labors are often blamed for squeezing the job opportunities and lowering the local wages. Macau is facing the dilemma that the local companies are expecting introducing more foreign labors to satisfy the rapid growth, but the local citizens are strongly protesting the foreign labors although the government has already controlled the import of outside workers to achieve the objective in regulating labor inflows so that foreign workers are made available only to supplement native workers and not to replace them, which is a contentious issue in policy debates in labor importing countries (Ducanes and Abella 2008, Hugo 2004, Lee 2002).

This paper aims to show the impact of foreign labor dependence on inter-industry wage differentials by using vector autoregressive (VAR) model and the impulse response analysis to investigate the interaction effects and response path between inflowing labors and wages in various industries based on 2003-2011 quarterly data. The results showed that inflowing labors would play long-term effects on manufacturing, construction, financial and tourism industrial wages.

\section{Modeling}

Borjas $(1999,2003)$ claims the importation of foreign labors may reduce the labor demand for native workers. And assuming the labor supply of native workers remains constant, the rate of wage return of native workers will decline. Aydemir and Borjas (2007) claim that the immigrant will increase labor supply, and lead to the negative effect in the wage of competing native employees. And the existing literatures also shown the number of foreign workers and their job types are important factors that affect the wages of the corresponding group of native workers. Borjas (2003) indicates the labor market implications of this supply shock will depend on how the distribution of work experience of foreign workers contrasts with that of native workers. On the other hand, the immigration will benefit to the less educated workers, leading to the smaller wage gap between less educated and highly educated native workers (Docquier et al., 2011). With regard to the occupation, foreign workers replace low-qualified workers, but complements high-qualified native workers, and the importation of foreign workers produces a positive wage effect on native workers (De New and Zimmerman, 1994).

\section{A. Vector Autoregression}

Based on the above studies, this paper will examine the effect of inflowing workers presence on wages in various industries by estimating the following VAR model.

A VAR model describes the evolution of a set of $k$ variables (endogenous variables) over the same sample period $(t=1, \ldots, T)$ as a linear function of only their past evolution. 
The variables are collected in a $k \times 1$ vector $y_{t}$, which has as the ith element $y_{i}$.

A (reduced) $p$-th order $\operatorname{VAR}$, denoted $\operatorname{VAR}(p)$, is

$$
y_{t}=c+\phi_{1} y_{t-1}+\cdots+\phi_{p} y_{t-p}+\varepsilon_{t}
$$

where $c$ is a $\mathrm{k} \times 1$ vector of constants (intercept), $\phi_{i}$ is a $\mathrm{k} \times \mathrm{k}$ matrix(for every $\mathrm{i}=1, \ldots, \mathrm{p}$ ) and $\varepsilon_{t}$ is a $\mathrm{k} \times 1$ vector of error terms.

So the VAR model for estimating the effect of inflowing labors on industrial wages goes as

$$
\begin{aligned}
\ln W G_{i t}= & \alpha \sum_{j}^{p} \beta_{j} \ln W G_{i(t-j)}+\sum_{j}^{r} \varphi_{j} \ln F L M_{(t-j)}+\sum_{j}^{r} \varphi_{j} \ln F L C_{(t-j)} \\
& +\sum_{j}^{q} \varphi_{j} \ln F L F_{(t-j)}+\sum_{j}^{n} \varphi_{j} \ln F L T_{(t-j)}+\varepsilon_{i t}
\end{aligned}
$$

Where $F L_{t-j}$ is the quantity of foreign labors in chosen industry; $W G_{i t}$ is the median of wage in i industry at time $t$; and $i$ indicates the manufacturing industry $(M)$, construction industry $(C)$, financial industry $(F)$ and tourism industry; $p, r$, $q$ and $n$ indicate the lag period.

The quarterly data on foreign labors and wages in manufacturing, construction, financial and tourism industries were compiled from statistic database of Statistics and Census Service from Government of Macao Special Administrative Region from 2003-2011.

\section{B. Unite Root Tests and VAR Lag Order Selection}

We couch our model in logarithmic difference form to induce stationarity. The legitimacy of this is establishing using Augmented Dickey-Fuller test (ADF). The results are presented in Table I and they confirm that the log changes are all without intercept and trend. The test statistic of ADF are compared with critical values given in MacKinnon (1991). To ensure that disturbance variables in all these equations are white noise, a sufficient number of lagged differences or truncated lag, have been estimated using Akaike Information Criteria (AIC).

TABLE I ADF Sequence Stationary Testing

\begin{tabular}{|l|c|c|c|c|}
\hline \multicolumn{1}{|c|}{ Variable } & $\begin{array}{c}\text { Test Form } \\
(\mathrm{C}, \mathrm{T}, \mathrm{K})\end{array}$ & $\begin{array}{c}\text { ADF } \\
\text { Statistics }\end{array}$ & Threshold & Conclusion \\
\hline$\Delta$ LnFLm & $(\mathrm{N}, \mathrm{N}, 0)$ & -2.4672 & $-2.6369^{* * *}$ & Stable \\
\hline$\Delta$ LnFLc & $(\mathrm{N}, \mathrm{N}, 0)$ & -2.7547 & $-2.6369^{* * *}$ & Stable \\
\hline$\Delta$ LnFLf & $(\mathrm{N}, \mathrm{N}, 0)$ & -2.5226 & $-2.6369^{* * *}$ & Stable \\
\hline$\Delta$ LnFLt & $(\mathrm{N}, \mathrm{N}, 0)$ & -3.1326 & $-2.6369^{* * *}$ & Stable \\
\hline$\Delta$ LnWGm & $(\mathrm{N}, \mathrm{N}, 0)$ & -6.1072 & $-2.6369^{* * *}$ & Stable \\
\hline$\Delta$ LnWGc & $(\mathrm{N}, \mathrm{N}, 0)$ & -4.6469 & $-2.6369^{* * *}$ & Stable \\
\hline$\Delta$ LnWGf & $(\mathrm{N}, \mathrm{N}, 0)$ & -8.6616 & $-2.6369^{* * *}$ & Stable \\
\hline$\Delta$ LnWGt & $(\mathrm{N}, \mathrm{N}, 0)$ & -3.7439 & $-2.6369 * * *$ & Stable \\
\hline
\end{tabular}

note:(i) $\mathrm{C}, \mathrm{T}, \mathrm{K}$ indicate intercept, time trend and lags in $\mathrm{ADF}$ test, $\mathrm{N}$ indicates without trend, $\triangle$ indicate first difference variance.

(iii) $* * *, * *, *$ indicate significant at the $1 \%, 5 \%, 10 \%$ level
TABLE II Lag Lengths Testing of VAR

\begin{tabular}{|c|c|l|l|l|l|l|}
\hline Group & LAG & \multicolumn{1}{|c|}{ LR } & FPE & AIC & SC & HQ \\
\hline M & 2 & 37.085 & $1.32 \mathrm{e}-11^{*}$ & $-10.991^{*}$ & -8.497 & -10.152 \\
\hline C & 2 & $58.331^{*}$ & $3.62 \mathrm{e}-12^{*}$ & $-12.287^{*}$ & $-9.793^{*}$ & $-11.448^{*}$ \\
\hline F & 2 & $52.381^{*}$ & $1.90 \mathrm{e}-11^{*}$ & $-10.632^{*}$ & -8.138 & $-9.7929^{*}$ \\
\hline T & 2 & $46.764 *$ & $2.17 \mathrm{e}-12^{*}$ & $-12.797 *$ & -10.303 & $-11.958^{*}$ \\
\hline
\end{tabular}

Unit root tests on the first difference of all series show the rejection of null hypothesis in 1 level form in the autoregression representation of each variables, that means they are all I(1). Furthermore, the choice of lag lengths, 2, for the VAR is chosen on the basis of several statistitical criteria (Table II).

\section{Estimation for the model}

The regression results of VAR model are showed as follows:

$$
\begin{aligned}
\operatorname{LnWGm}= & 0.136 * \operatorname{LnWGm}(-1)+0.046 * \operatorname{Ln} W G m(-2) \\
& -0.378^{*} \operatorname{LnFLm}(-1)-0.268 * \operatorname{LnFLm}(-2) \\
& +0.007 * \operatorname{LnFLc}(-1)+0.03{ }^{*} \operatorname{LnFLc}(-2) \\
& -0.101 * \operatorname{LnFLf}(-1)-0.03{ }^{*} \operatorname{LnFLf(-2)} \\
& -0.044 * \operatorname{LnFLt}(-1)+0.186 * \operatorname{LnFLt}(-2) \\
& +11.815
\end{aligned}
$$

$R^{2}=0.924 \quad F=26.786 \quad$ AIC $=-2.465 \quad S C=-1.966$

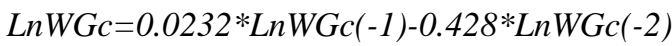

$$
\begin{aligned}
& +0.419 * \operatorname{LnFLm}(-1)-0.6 * \operatorname{LnFLm}(-2) \\
& +0.036 * \operatorname{LnFLc}(-1)+0.003 * \operatorname{LnFLc}(-2) \\
& +0.309 * \operatorname{LnFLf}(-1)-0.076 * \operatorname{LnFLf}(-2) \\
& +0.03 * \operatorname{LnFLt}(-1)+0.141 * \operatorname{LnFLt}(-2) \\
& +11.151
\end{aligned}
$$

$R^{2}=0.988 \quad F=191.169 \quad$ AIC $=-3.578$ SC $=-3.079$

$L n W G f=0.297 * L W G f(-1)+0.034 * \operatorname{LnWGf}(-2)$

$$
\begin{aligned}
& +0.717 * \operatorname{LnFLm}(-1)-0.811 * \operatorname{LnFLm}(-2) \\
& -0.114 * \operatorname{LnFLc}(-1)+0.097 * \operatorname{LnFLc}(-2) \\
& -0.019 * \operatorname{LnFLf}(-1)+0.1 * \operatorname{LnFLf}(-2) \\
& -0.276 * \operatorname{LnFLt}(-1)+0.308 * \operatorname{LnFLt}(-2) \\
& +6.539
\end{aligned}
$$

$$
R^{2}=0.924 \quad F=26.786 \quad \text { AIC }=-2.46 \quad S C=-1.966
$$

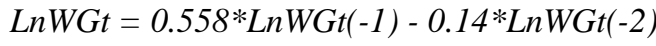

$$
\begin{aligned}
& -0.191 * \operatorname{LnFLm}(-1)-0.028 * \operatorname{LnFLm}(-2) \\
& -0.019 * \operatorname{Ln} F \operatorname{Lc}(-1)+0.05 * \operatorname{LnFLc}(-2) \\
& +0.085 * \operatorname{Ln} F L f(-1)-0.144 * \operatorname{Ln} F \operatorname{Lf}(-2) \\
& +0.016 * \operatorname{LnFLt}(-1)+0.1 * \operatorname{LnFLt}(-2) \\
& +6.375
\end{aligned}
$$

$R^{2}=0.995 \quad F=461.52 \quad A I C=-4.758 \quad S C=-4.259$ 
The coefficients of regressions are statistically significant at 5 percentages, and the regression models pass the general significance test. And every models' inverted roots of the lag polynomial lie inside the unit circle, denoting the stationarity condition for general AR processes.

\section{Impulse Response Analysis}

Then this paper conducts the impulse-response analysis which describes the reaction of one variable to the innovations in another variable in the system, while holding all other shocks equal to zero. In this specification we assume that current shocks to the marginal inflowing of outside workers in different industries have impact on the contemporaneous value of the wages of different industries.

An impulse response refers to the reaction of any dynamic system in response to some external change. A VAR was written in vector $M A(\infty)$ form as

$$
\begin{aligned}
& y_{t}=\sum_{i=0}^{\infty} \phi_{i} \varepsilon_{t-i} \quad \phi_{0}=I_{n} \\
& y_{t+n}=\sum_{i=0}^{\infty} \phi_{i} \varepsilon_{t+n-i}
\end{aligned}
$$

Impulse responses function is

$$
\left\{\varphi_{n}\right\}_{i, j}=\frac{\partial y_{i t+n}}{\partial \varepsilon_{j t}}
$$

which describes the response of $y_{i, t+n}$ to a one-time impulse in $y_{j, t}$ with all other variables dated $t$ or earlier held constant.

Fig. 1 reports graphs of impulse responses for the industrial wages to inflowing labors in different industries.

According to Fig. 1, the shock of inflowing labors in manufacturing industry to manufacturing industrial wages reaches the maximum 0.023 negative effect at the $3 \mathrm{rd}$ period, and the negative effect turns into 0.002 positive effect at the 12 th period, which indicates the inflowing workers in manufacturing industry lower the industrial wages quickly in the short term, and keep negative effect on the manufacturing industrial wages in next 3 years. The shock of inflowing labors in financial industry to manufacturing industrial wages reaches the maximum 0.006 negative effect at the 1 st period, and turns into 0.009 positive effect at the 10th period, which shows little impact on manufacturing industrial wages. The shocks of inflowing labors in construction and tourism industry to manufacturing industrial wages keep unstable.

The shock of inflowing labors in construction industry shows sustainably positive impact on construction industrial wages and reaches maximum 0.02 at 6 th period. The inflowing labors in constructing industry is a hot issue in Macau because the inflowing workers in construction industry are required professional skills which cause their wages are higher than low skill workers in the same industry and increase the whole level of industrial wages. But the pull effect is weakened due to the wages of inflowing workers in construction industry are only equal to $60 \%$ of same level skill native workers. Lacking of high skilled native workers in constructing industry causes the contradictions between native job opportunities and wages of foreign high skilled workers. Meanwhile, along with rapid expansion of tourism and hotels construction, the shock of inflowing labors in constructing industry also shows constant positive impact on tourism industrial wages.
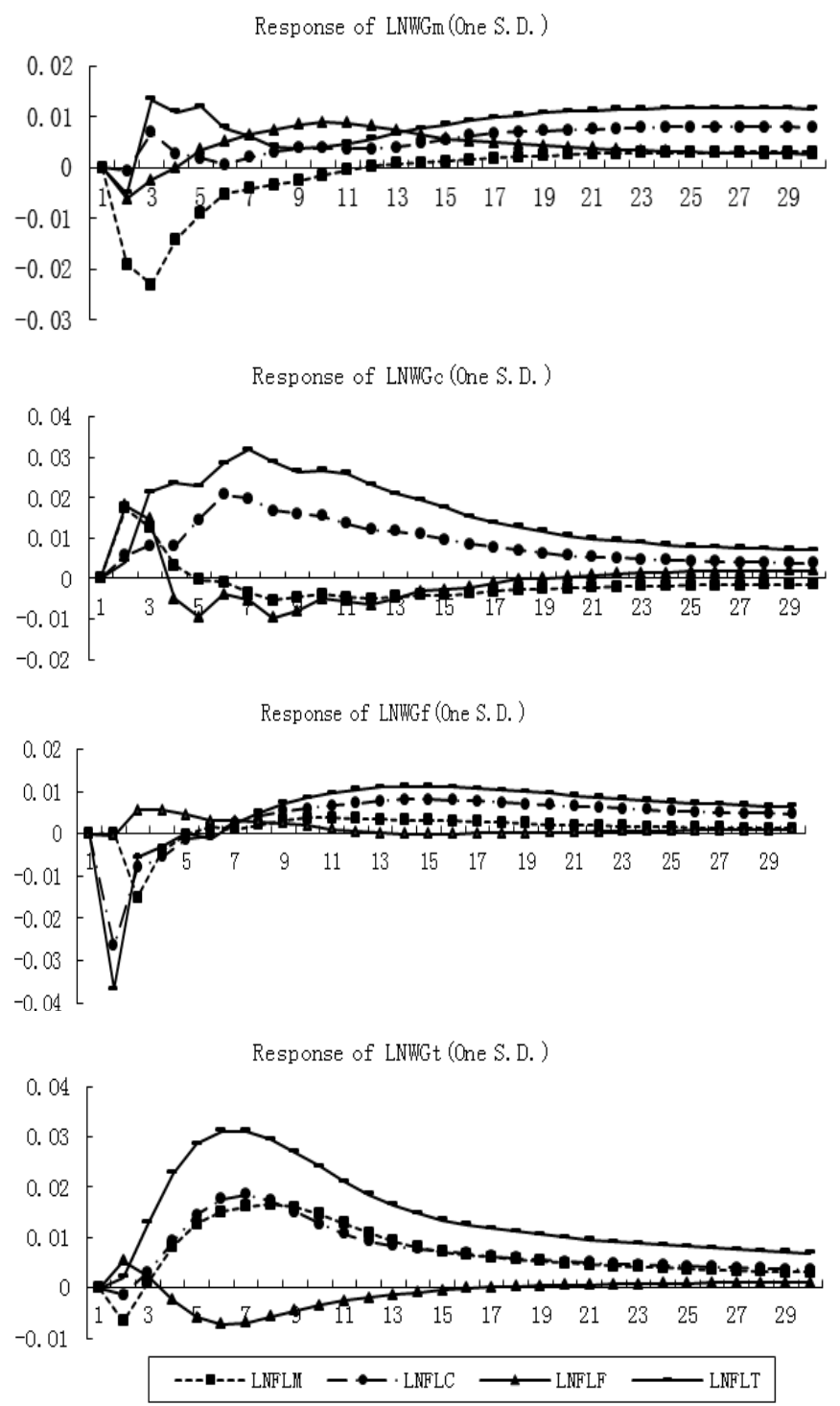

Fig. 1 Impulse Response of Industrial Wages to Inflowing Labors

In the financial industry, the shock of inflowing workers only plays a faint negative impact on the industrial wages, and starts positive impact from 2 nd period, then keeps stable after reaching the peak 0.005 at 3 rd period. The financial industry is also facing skills shortage as a emerging industry in Macau, comparing to the quick expansion of tourism and gambling industry. The employees turnover is about $10 \%$ to $25 \%$ in financial industry. Therefore the inflowing workers in tourism industry relieve the labor shortage and lower the industrial wages level in financial industry mediately. The shock of 
inflowing foreign financial workers plays negative impacts in first 6 period on tourism industrial wages. But in the long term, the inflowing workers in financial industry boost the wages in tourism industry as a result of retain the employees from gathering in highly developed and well paid tourism industry.

The tourism industry is the critical support for Macau with a development growth rate about $30 \%$ per year. And the wages of tourism industry keep climbing to absorb more and more native workers entering this industry. Therefore the shock of inflowing workers in tourism industry has a positive impact on industrial wages in the long term, but lowers the manufacturing and financial industrial wages in the short term.

\section{Conclusion}

This paper uses a vector auto-regressive (VAR) approach to analysis the relationship between industrial inflowing workers and wages. It shows that inflowing workers play significant impact on industrial wages. More specifically, the impact of the shock of constructing foreign workers on wages is positive, while the other three are negative significant, which indicate the cheap inflowing labors reduced the wage costs and provide necessary human resources Macau.

And although the importion of foreign workers lowers the wages of tourism industry in the short term, it shows a positive impact in the long term not only on elevating the tourism wages and absorbing the native labors, but also on other three industrial wages by causing the shortage in other industries, and forcing other industries to elevate the wages to attract qualified workers.
With the development of Macau economy, the shortage in working labors and the objection to inflowing workers by native citizens are both more severe. To solve these problems, Macau government must improve local labors' professional technical abilities through the higher education and training, and establish complementary employment relation between inflowing and local labors to promote the harmonious development of both sides.

\section{References}

[1] Ducanes, G. and M. Abella (2008). Labour shortage responses in Japan, Korea, Singapore, Hong Kong and Malaysia: a review and evaluation, ILO Asian Regional Programme on Governance of Labour Migration, Working Paper No.2, International Labour Organization (ILO): Geneva.

[2] Hugo, Graeme (2004). International labour migration in the Asia-Pacific region: emerging trends and issues, in D.S. Massey and J.E. Taylor (eds.), International Migration: Prospects and Policies in a Global Market (New York: Oxford University Press), pp.77-103.

[3] Lee, Joseph (2002). The role of low-skilled foreign workers in Taiwan's economic development, Asia Pacific Business Review, 8(4): 41-66.

[4] Borjas, G. 1999. "The Economics Analysis of Immigration," Handbook of Labor Economics, eds. Ashenfelter O. and Card D. Amsterdam, 3(a), 1697-1760.

[5] Borjas, G. 2003. "The Labor Demand Curve is Downward Sloping: Reexamining the Impact of Immigration on the Labor Market," Quarterly Journal of Economics, 118(1), 1335-1374.

[6] Aydemir, A. and G. J. Borjas. 2007. "Cross-Country Variation in the Impact of International Migration: Canada, Mexico, and the United States," Journal of the European Economic Association, 5(4), 663-708.

[7] Docquier, F., Ç. Özden, and G. Peri. 2011. "The Wage Effects of Immigration and Emigration," Policy Research Working Paper 5556, World Bank, February 2011.

[8] De New, J. P. and K. F. Zimmerman.1994. "Native Wage Impacts of Foreign Labor: A Random Effects Panel Analysis," Journal of Population Economics, 7(2), 177-192. 